J. Perinat. Med. 5 (1977) 39

\section{Acute reduction of uterine blood flow and fetal heart rate changes in pregnant sheep near term}

\author{
Heinz-Dieter Junge, Wolfgang Künzel, Friedrich Karl Klöck \\ Universitäts-Frauenklinik Würzburg (Head: Prof. Dr. K.-H. WULF) \\ Frauenklinik der RWTH Aachen (Head: Prof. Dr. H. JUNG)
}

Vigorous uterine contractions may be the cause of repetitive acute reductions of uterine blood flow (UBF) (Fig. 1) $[1,2,6,8,15,23,33]$ and the cause of decelerations of the fetal heart rate (FHR). Although this fact is of great interest for the evaluation of FHR recordings during parturition little is known about quantitative aspects. Assalı et al. [3] reported a FHR decrease (= deceleration amplitude) of $10 \mathrm{bpm}$ with a $25 \%$ reduction of $\mathrm{UBF}$, a deceleration of $20 \mathrm{bpm}$ with a $50 \%$ reduction of UBF and a deceleration of $68 \mathrm{bpm}$ with a 90\% reduction of UBF (Mean values) in fetal lambs in utero. Basal UBF and basal FHR prior to UBF reduction were not taken into consideration. Yet it is known that there is a decrease in basal UBF in chronic and subchronic uteroplacental insufficiency in man [9]. So we were interested to reevaluate the quantitative relationships between basal UBF, basal FHR, the amount of acute repetitive UBF reduction and FHR changes.

\section{Material and methods (Fig. 2)}

1.1 Five merino sheep near term were used for acute preparations. Maternal weight was $66,6 \mathrm{~kg}$ (Mean). Mean fetal weight was 4,2 kg. Three sheep had a single fetus and two had twin fetuses.

1.2 For recording and later evaluation of signals a multi-channel pen recorder (Hellige) and a multi-

\section{Curriculum vitae}

HEINZ-DIETER JUNGE, M.D. Born in Kiel, 1935. Studying Medicine at the University of Kiel. 19631969 Staff member, Department of Obstetrics and Gynecology, University of Kiel. In 1969 taking a and Computer Technique at the Bioelectronic and Computer Labs of the Cardiologic Branch, Pediatric Department, University of Kiel on a grant of the "Stiftung Volkswagenwerk".

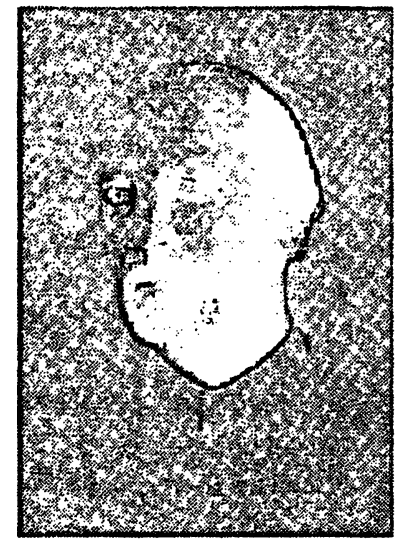
1970-1973 Staff member,

Department of Obstetrics and Gynecology, Medizinische Hochschule Hannover. Since 1973 Lecturer (Privatdozent), Department of Obstetrics and Gynecology, University of Würzburg. Fields of interest: Technical and clinical aspects of cardiotocography, fetal cardiovascular regulation and state of arousal. Main present interest: Computer aided CTG-Monitor-Systems (CMS).

channel analog tape (Philips) were used. Calibration of heart rate meters with a function generator and of electro-manometers with a Hg-manometer was performed before the beginning and after the end of each experiment. Preliminary calibration of the flow meter was achieved by running definite amounts of $\mathrm{NaCl}$-solution per time through a catheter fitted into the flow meter cup. For definite calibration this procedure was repeated at the end 
SHEEP No. 20

t $(\min )$
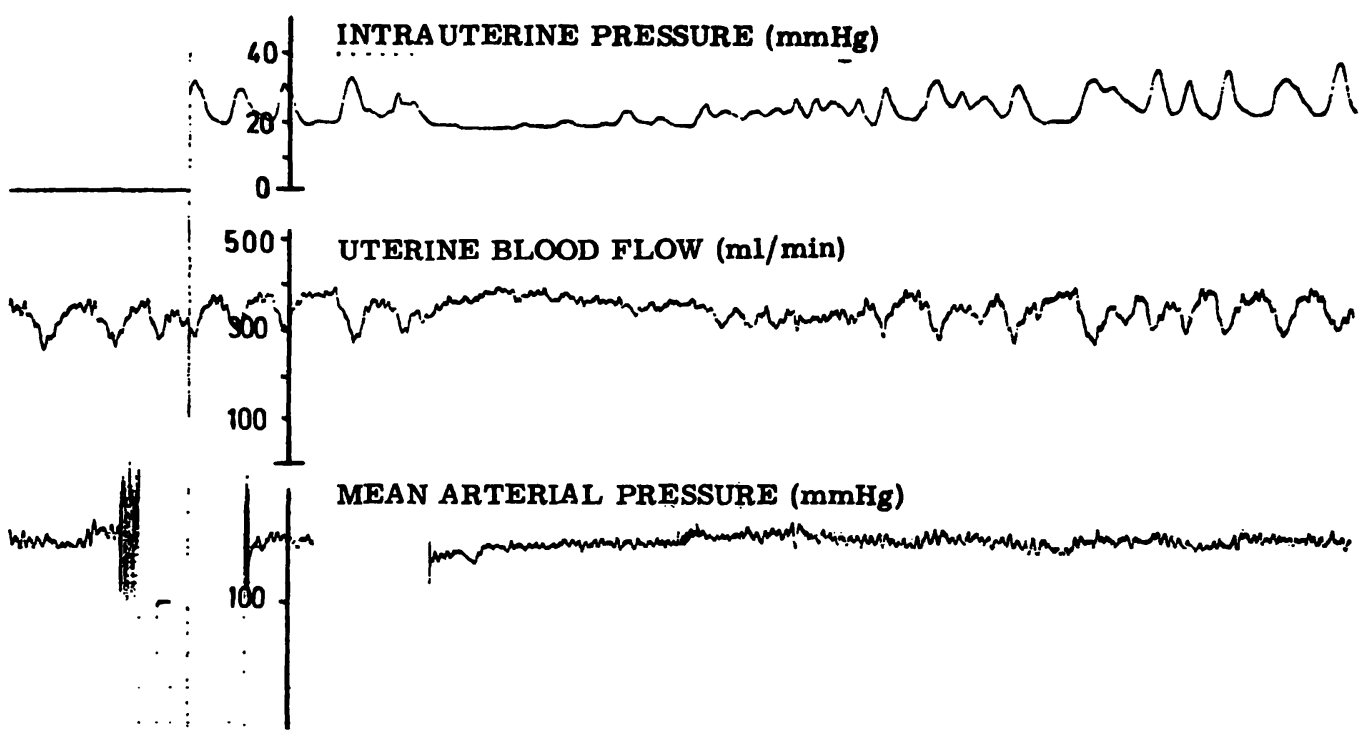

Fig. 1. Simultaneous recording of intrauterine pressure, uterine blood flow and mean arterial pressure in a pregnant sheep. Contraction elicited decreases in uterine blood flow can be seen clearly.

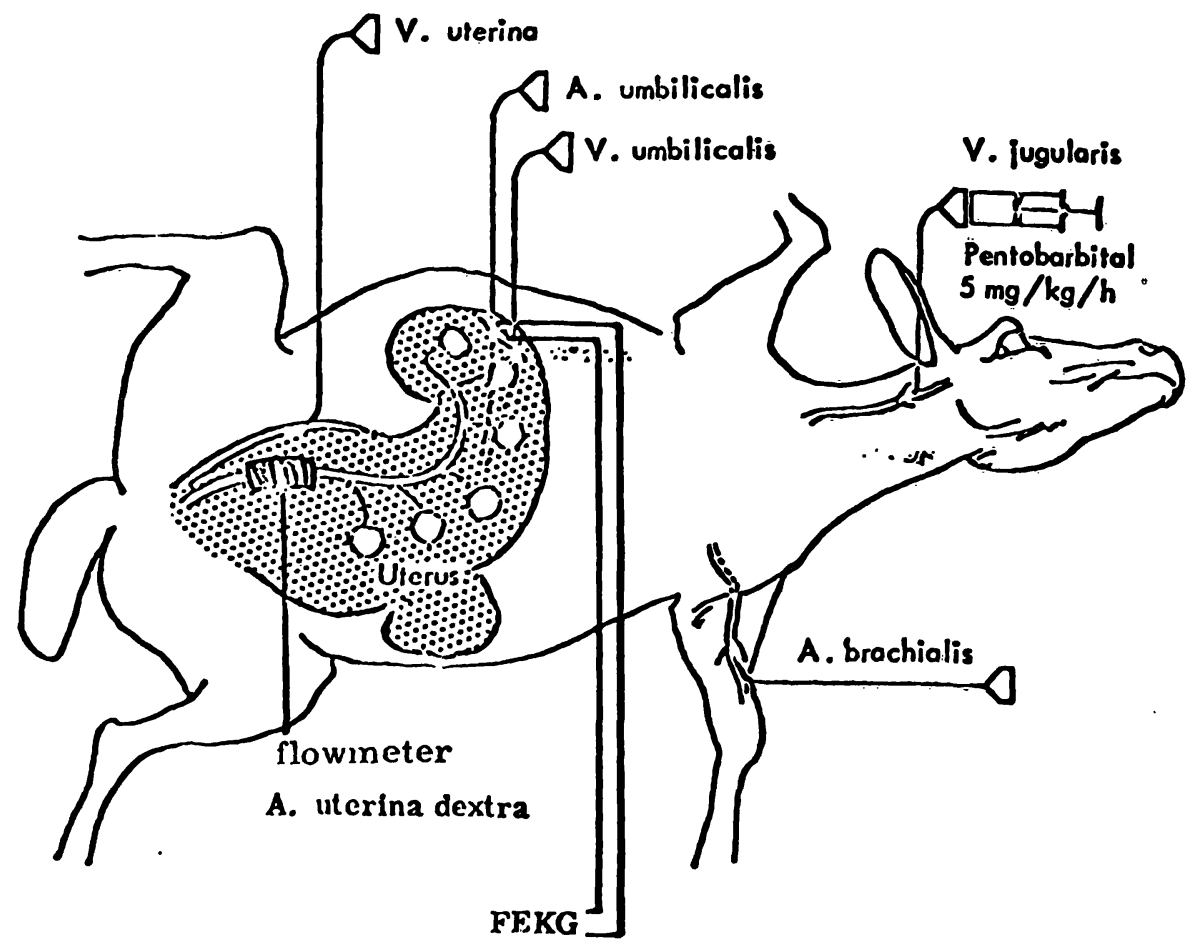

Fig. 2. Diagram showing the experimental set up. 
of each experiment using the ewes' own blood running from the carotid artery.

1.3 The ewes were anaesthezised with pentobarbital (initial dose $20 \mathrm{mg} / \mathrm{kg}$ i.v., continued by infusion of $5 \mathrm{mg} / \mathrm{kg} / \mathrm{h}$ ) and Alloferin was given for relaxation. The ewe was then placed on a surgical table in left lateral position. After tracheotomia intubation was performed and ventilation was maintained by a Starling pump. Electrodes were attached to the maternal chest for recording maternal ECG and heart rate. Polyethylene tubes were inserted into the jugular vein for administering the anaesthetic and into the brachial artery for recording arterial pressure via a pressure transducer. The abdominal wall was opened by a right lateral section and the uterine horn containing the fetus was partially exposed. First of all thin catheters were inserted into branches of the umbilical artery and umbilical vein through small incisions of the uterine wall leaving the amnion intact. Fetal ECG and FHR were recorded via very thin, partially unisolated platinum wires inserted subcutaneously into the fetal back by puncturing the uterine wall and the fetal skin with a long puncture needle. Another catheter was inserted into the uterine cavity by puncturing its wall for recording intrauterine pressure. Both uterine arteries were freed from surrounding tissues after infiltration with local anaesthetics to prevent spasm. Firstly the artery of the gravid horn was inserted into the cage of the flow meter cup and blood flow was recorded for some time. The measurement was taken valid when blood flow was stable. Then the flow meter cup was put around the artery of the other side and blood flow was measured in the same way. Both measurements were added and taken as total uterine blood flow. At last the flow meter cup was put back around the artery of the gravid horn again and then the abdominal wall was closed. Now the calibration scale of the blood flow channel was corrected according to the initial ratio of flows in both uterine arteries presuming that this ratio would remain constant throughout the course of the experiment.

1.4 Blood samples drawn form the catheters were kept in glass capillaries at low temperature until analyses of $\mathrm{pO}_{2}, \mathrm{pCO}_{2}$, and $\mathrm{pH}$ were performed. These were done with an Eschweiler appartus.

1.5 Investigationson UBF reduction and fetal response were started at various times after initial surgical preparation depending on our program of several items being investigated in each preparation. At that time different degrees of deterioration of the ewes and hence the fetuses were seen but this was in agreement with our experimental intentions. Repetitive and progressive acute reduction of UBF (approximately 25\%, 50\% and 100\% from basal UBF value) was achieved three times, lasting 120 sec each and each approximatly 12 min apart, by flowmeter controlled partial or total occlusion of the aorta abdominalis of the ewe with a balloon

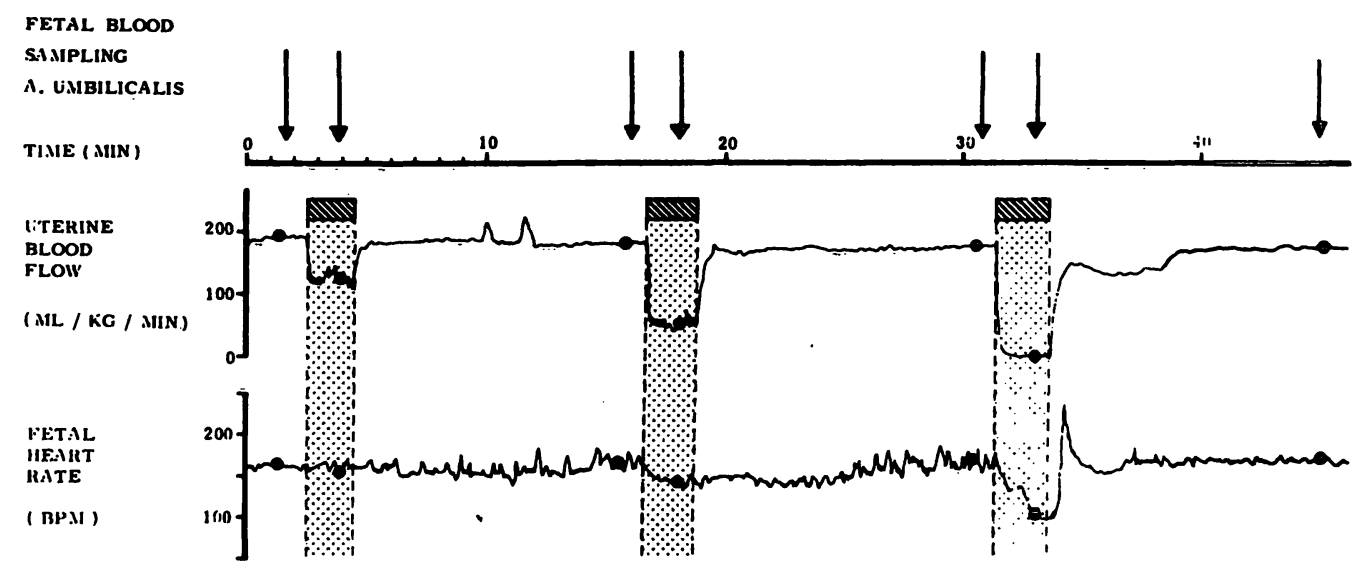

Fig. 3. Semischematic diagram showing data aquisition during repetitive acute flowmeter controlled reduction of uterine blood flow.

Blood sampling was performed discontinuously (arrows). Simultaneous data of UBF and FHR were taken from continuous recordings (black dots). 
catheter inserted into the aorta. (In some cases the lateral abdominal section was left open and the aorta was compressed manually).

Before, $90 \mathrm{sec}$ after the beginning and $10 \mathrm{~min}$ after the end of UBF reduction blood samples were taken from the fetal catheters (Fig. 3). In two preparations this sequence was repeated once after complete recovery of FHR.

\section{Results}

Data of all fetuses and all UBF reduction sequences are given in Table I and Fig. 4.

2.1 Data before and after UBF reduction sequence Initial UBF values ranged from 180 to $57 \mathrm{ml} / \mathrm{kg} / \mathrm{min}$ (Mean 104.0, SD $\pm 37.5 \mathrm{ml} / \mathrm{kg} / \mathrm{min}$ ). Thus situations with physiologic avlues of UBF, borderline situations
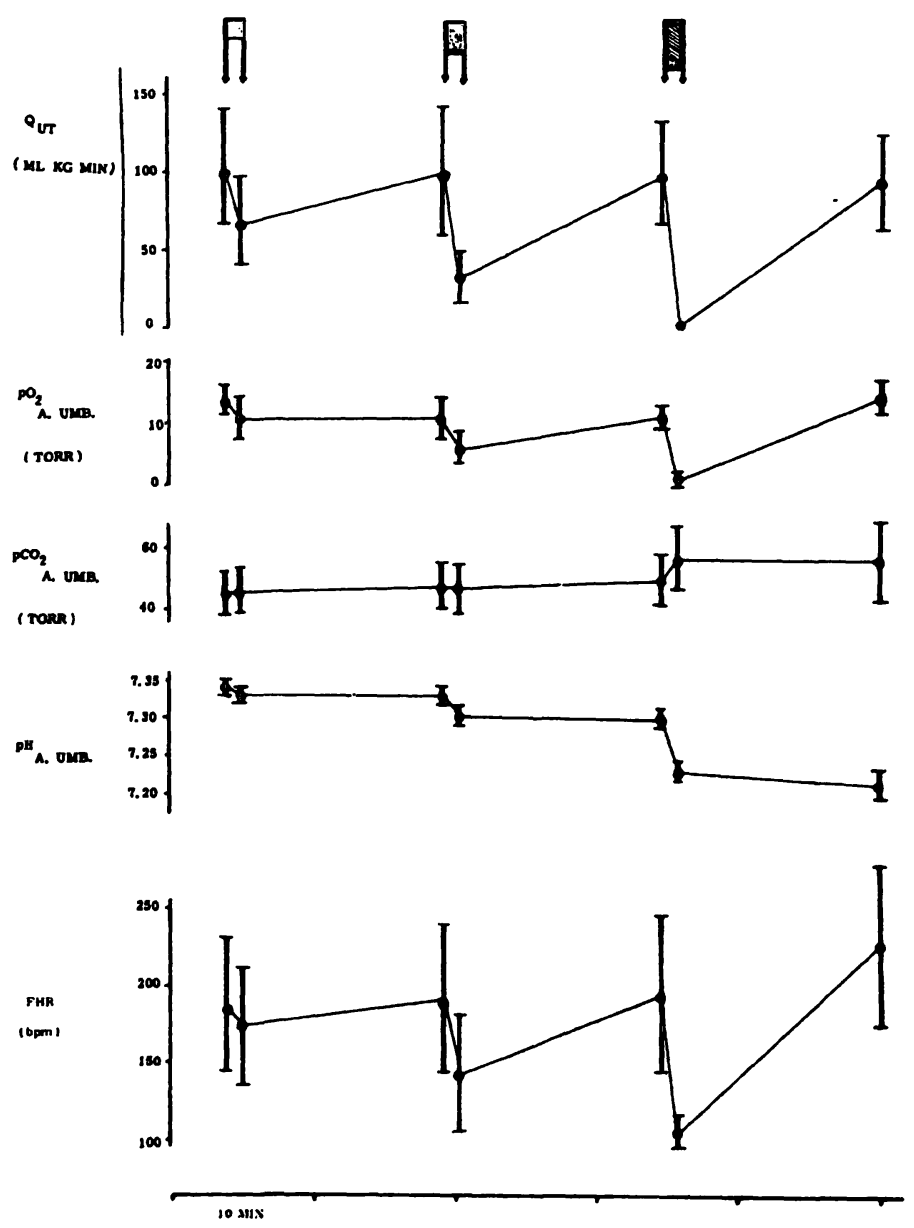

Fig. 4. Mean values of $\mathrm{UBF}, \mathrm{pO}_{2}, \mathrm{pCO}_{2}$ and $\mathrm{pH}$ in the umbilical artery as well as FHR for all $7 \mathrm{UBF}$ reduction sequences performed. (Arrows in upper part indicate UBF reduction). and situations with extremely pathologic UBF values could be investigated, which was in agreement with our experimental intentions.

$\mathrm{PO}_{2}$ in the umbilical artery ranged from 18.5 to 6 Torr (Mean 13.3, SD \pm 5.1 Torr), indicating moderate to severe fetal hypoxemia. Overall there was a combination of high UBF values with high $\mathrm{pO}_{2}$ values and vice versa, but correlation was not significant $r=.42,2 \alpha<.1$ ).

$\mathrm{PCO}_{2}$ in the umbilical artery was in the range of 37 to 57 Torr (Mean 44.9, SD \pm 6,7 Torr). No significant correlation to UBF could be found. PH in the umbilical artery ranged from 7.43 to 7,23 pH units (Mean 7.34, SD $\pm .06 \mathrm{pH}$ units) and there was no correlation to UBF.

FHR ranged from 130 to $235 \mathrm{bpm}$ (Mean 186.4, $\mathrm{SD} \pm 34 \mathrm{bpm})$. Thus a wide range of fetal cardiovascular situations was under investigation too. Except preparation No. 20 there was in inverse relationship between basal UBF and FHR $(r=-.48$, $2 \alpha<.05)$ and an inverse relationship between basal $\mathrm{pO}_{2}$ and FHR $(\mathrm{r}=-.46,2 \alpha<.05)$. Altogether low basal UBF was accompanied by fetal hypoxemia and tachycardia (Figs. 5 and 6).

2.2 Ten minutes after the whole UBF reduction sequence mean values for $\mathrm{UBF}$ and $\mathrm{pO}_{2}$ were not altered in comparison to initial values, $\mathrm{pCO}_{2}$ was elevated by 9.7 Torr, $\mathrm{pH}$ was lowered by $.13 \mathrm{pH}$ units. FHR had increased by 48.6 to $225 \mathrm{bpm}$.

2.3 Relationship between acute reduction of of UBF $\left(\Delta Q_{U T}\right)$ and FHR decrease $(\triangle F H R=$ deceleration amplitude).

The scattergram of $\triangle F H R$ versus $\Delta Q_{U T}$ prima vista does not show any relationship (Fig. 7). But transformation of the scattergram by taking $\triangle F H R$ and $\Delta$ QuT as percentage of basal values gives good results (Fig. 8). (100 bpm was defined as $\phi \%$ of basal FHR value because with $100 \%$ reduction of UBF heart rate of the fetal lamb decreased to about $100 \mathrm{bpm}$ (Mean 104.2, SD $\pm 10.5 \mathrm{bpm}$ )). In fact an alinear correlation can be seen. This fact must lead to the conclusion that $\Delta F H R / \Delta Q_{U T}{ }^{\prime}$ is dependent on basal UBF and FHR levels. In order to prove this the $\Delta F H R / \Delta A_{U T}$ were plotted versus basal UBF (Fig. 9) and basal FHR (Fig. 10). A significant alinear correlation can be found for both. Relations are inverse because of the inverse 


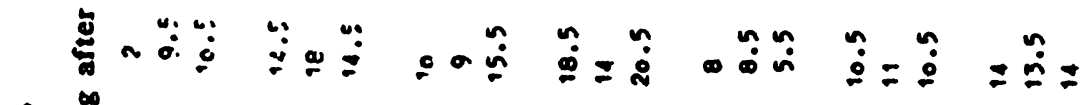

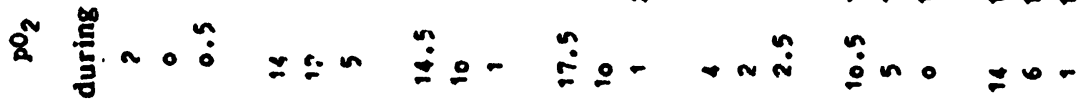

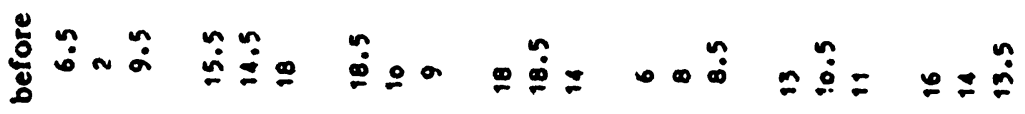

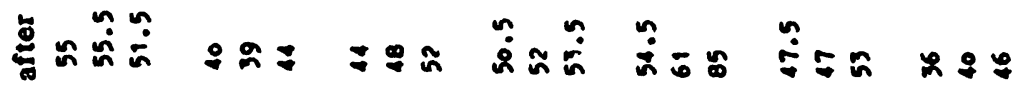

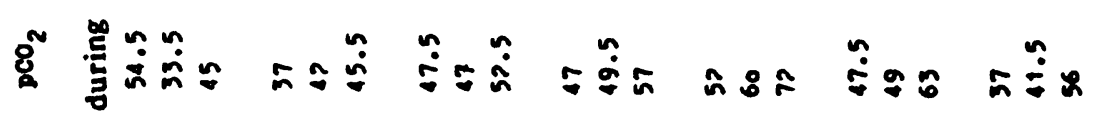

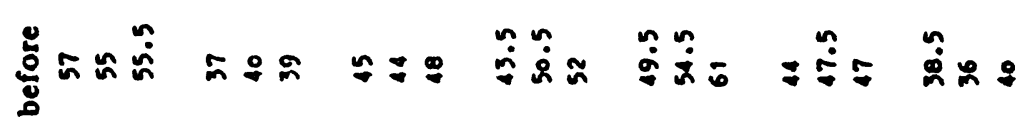

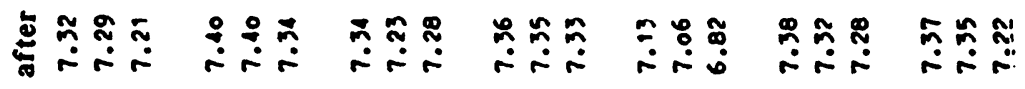

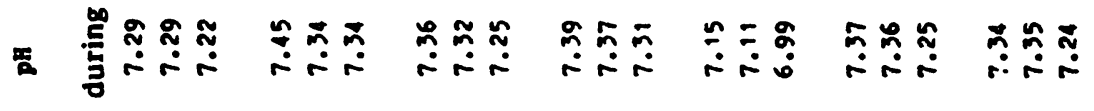

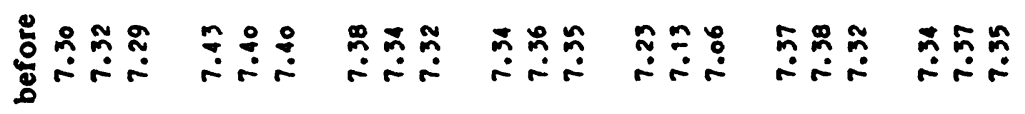

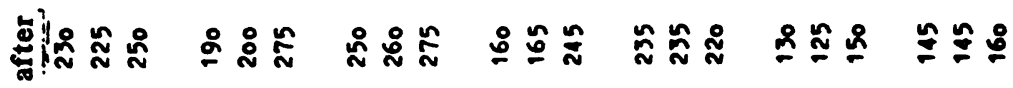

T:

空

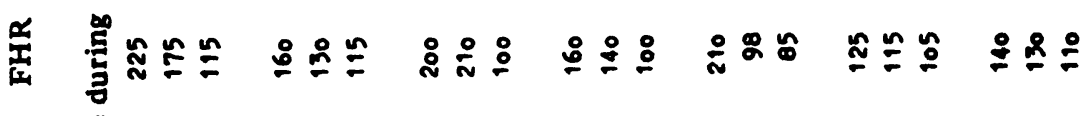

产

家员

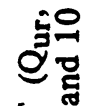

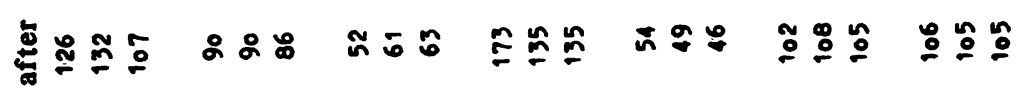

萝要

总 :

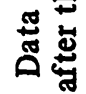

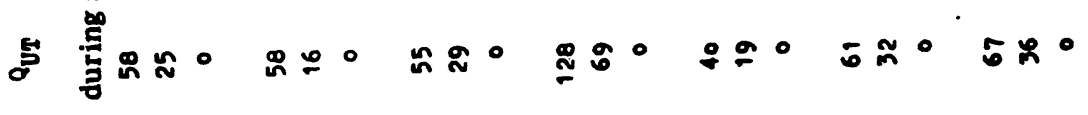

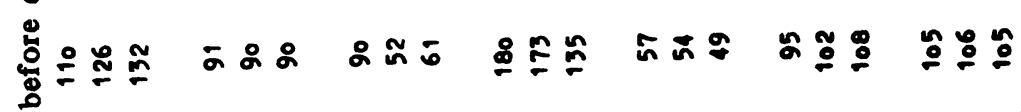

ㄷ․ㅇ

赵这

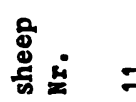

$\div \quad=$

\& 


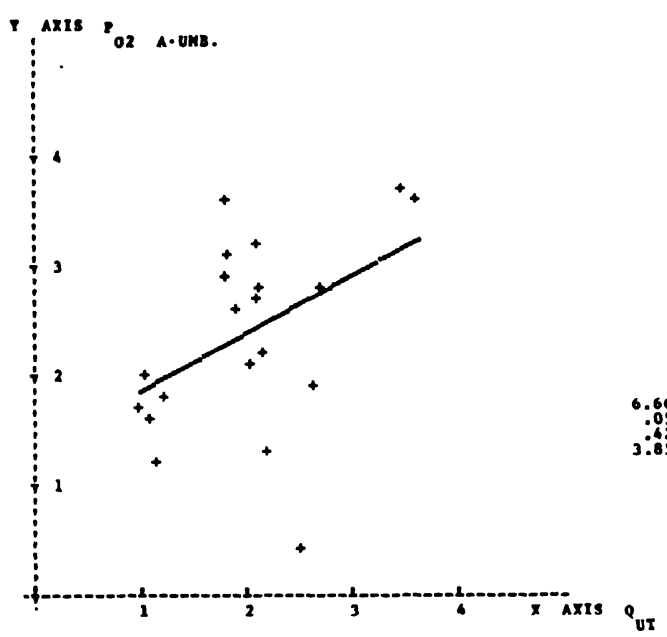

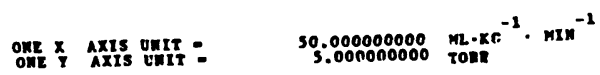

Fig. 5

LIKEAR REGRESSIOW AMALYSIS $(y-\infty(0)+\cdot(1) \times)$

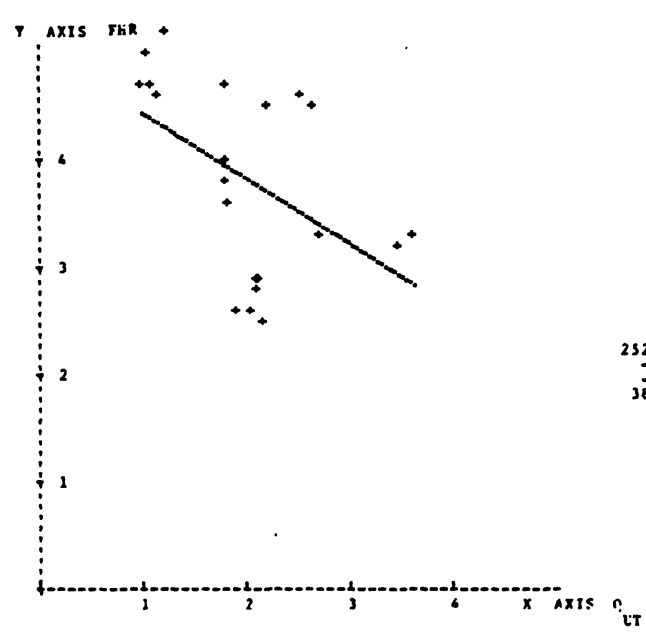

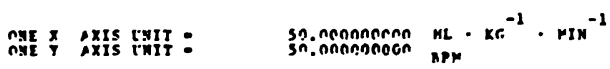

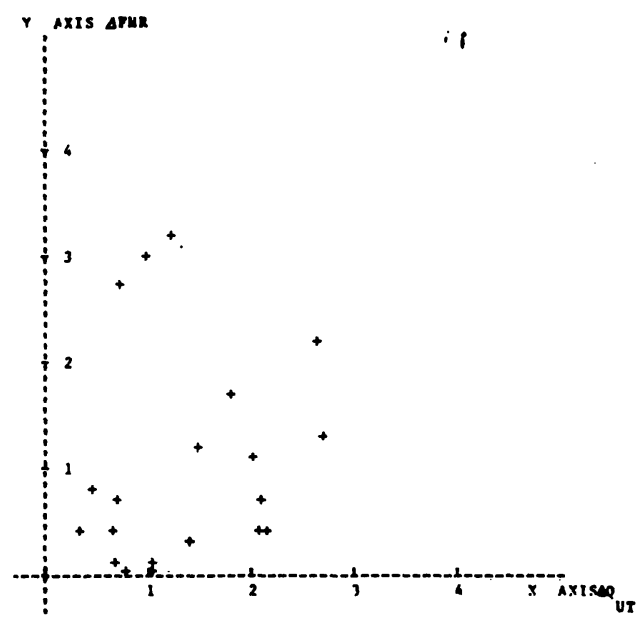

OKE Y

Fig. 7

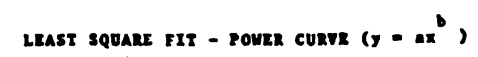

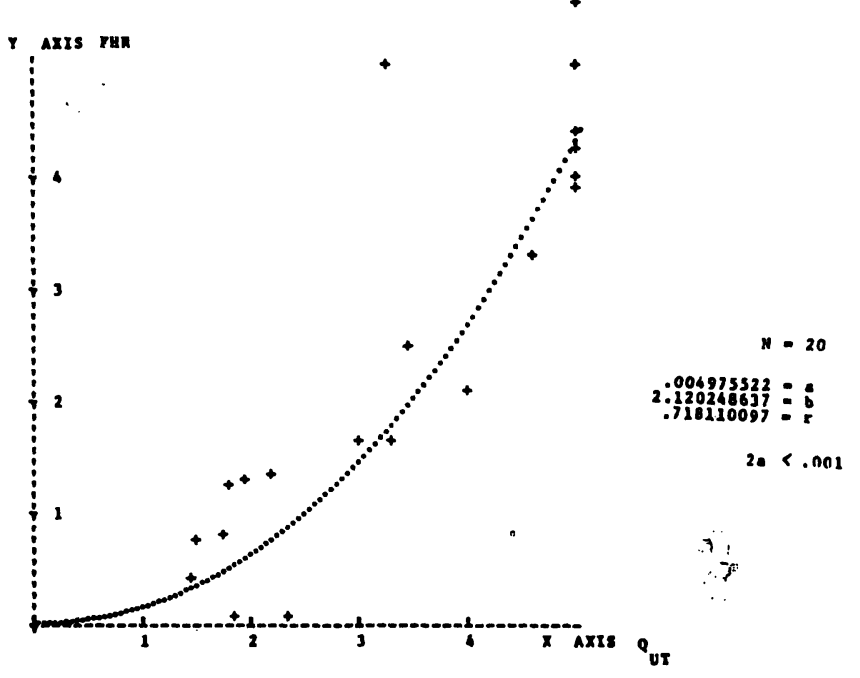

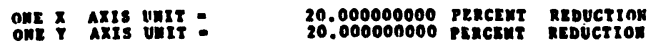

Fig. 6

Fig. 8

Fig. 5. Relationship between basal $\mathrm{pO}_{2}$ in the umbilical artery and basal UBF (QUT) prior to each UBF reduction.

Fig. 6. Relationship between basal FHR and basal UBF (QUT) prior to each UBF reduction.

Fig. 7. Scattergram of values of $\triangle F H R$ versus $\Delta Q U T$. No relationship for ungrouped values.

Fig. 8. Significant alinear correlation between $\triangle F H R$ and $\Delta Q U T$, both taken as percentage of basal values.

(100 bpm was defined as $\emptyset \%$ of basal FHR value, because with $100 \%$ UBF reduction the lowest FHR seen was about 100 bpm). 


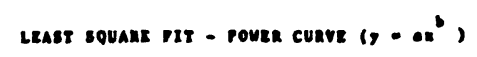

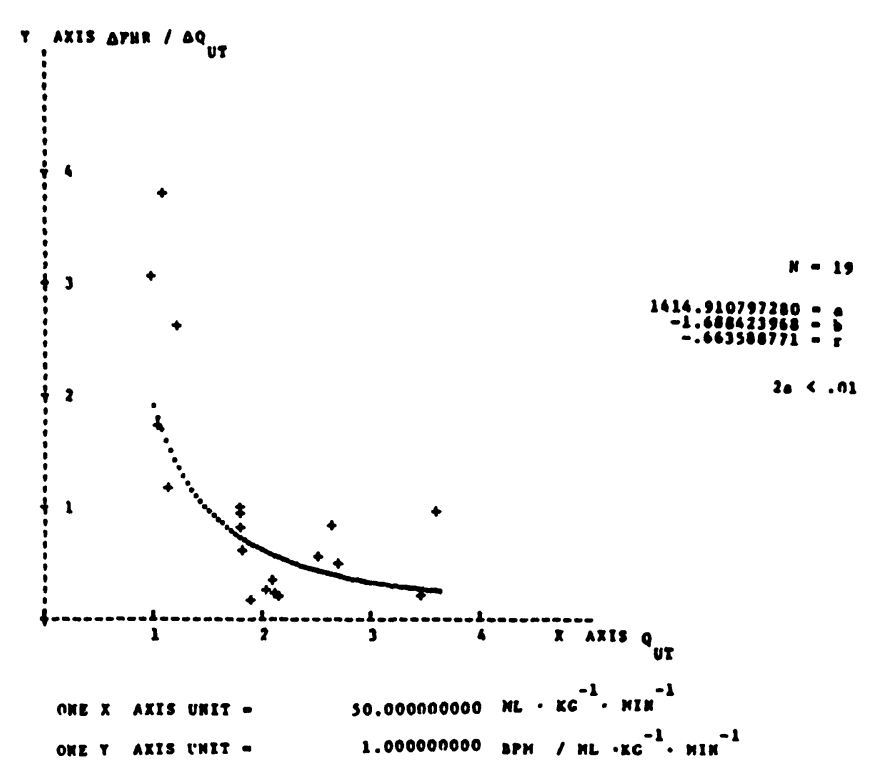

Fig. 9
Least squake nte - pouse curve $\left(y-\ldots x^{b}\right.$,

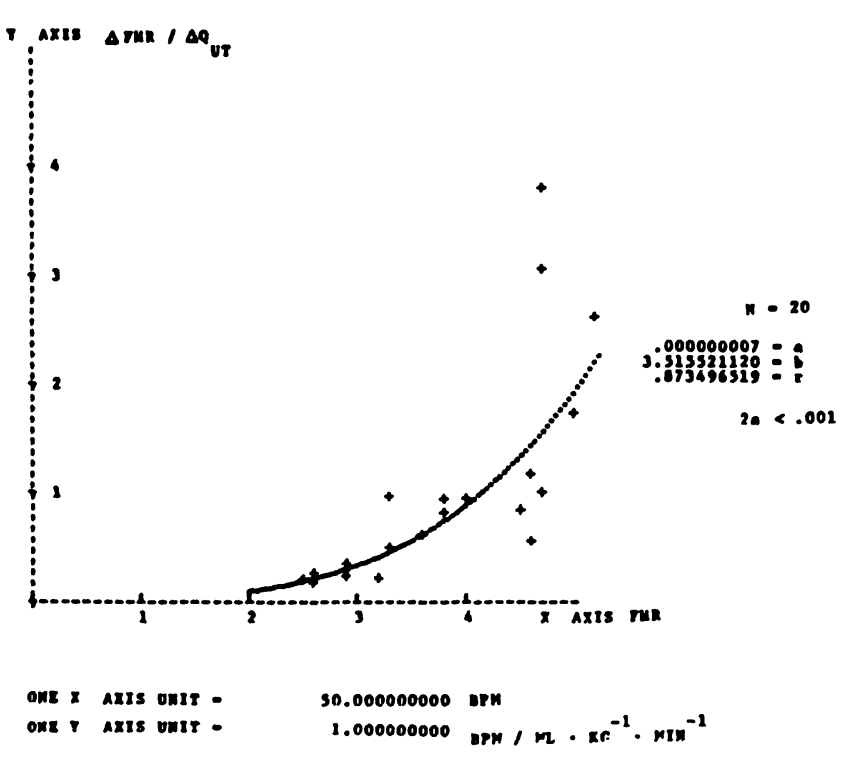

Fig. 10

Fig. 9. Significant alinear correlation between $\Delta F H R / \Delta Q U T$ ratio and basal UBF (QUT). Deceleration amplitude per unit of UBF decrease rises sharply when basal UBF is below $100 \mathrm{ml} / \mathrm{kg} / \mathrm{min}$.

Fig. 10 Significant alinear correlation between $\Delta F H R / \Delta Q U T$ ratio and basal FHR. Deceleration amplitude per unit of UBF decrease rises sharply when basal FHR is elevated to its maximum.

relationship between basal UBF and basal FHR (see above).

Reevaluation of the scattergram of $\triangle F H R$ versus $\Delta Q_{\text {UT }}$ anew by grouping data according to normal, prepathologic and pathologic basal levels of QUT (Fig. 11) and FHR (Fig. 12) gives sense now. Using the least square fit power curve $\left(y=a x^{b}\right)$ statistically significant alinear regression lines for the physiologic range of basal UBF (QuT $>100 \mathrm{ml}$ ) $\mathrm{kg} / \mathrm{min}$ ) and the physiologic range of basal FHR (FHR $<170$ bpm) may be fitted. For the intermediate and pathologic ranges alinearity is not statistically significant but because of the alinearity in the percentage regression (see Fig. 6) which includes all data, alinear regressions for the intermediate and pathologic ranges were calculated too.

From this the following conclusions may be valid: Within physiologic levels of UBF and FHR minor and moderate acute reductions of UBF do not affect FHR at all or lead to minor decelerations.
Only a substantial reduction will cause decelerations of larger amplitude. But with decreasing basal UBF levels (and increasing FHR levels) the same absolute amount of UBF reduction leads to increasing deceleration amplitudes.

\subsection{It is a widely accepted opinion that FHR} decelerations caused by acute UBF reduction are mediated by a fall in fetal $\mathrm{pO}_{2}$ via vagal stimulation and/or direct depression of the heart. Therefore it seemed interesting to evaluate relations between UBF and $\mathrm{pO}_{2}$ alterations as well as the relations between $\mathrm{pO}_{2}$ and $\mathrm{FHR}$ alterations.

2.4.1 Relationship between acute reduction of UBF ( $\left.\Delta Q_{U T}\right)$ and change of $\mathrm{pO}_{2}$ in the umbilical artery $\left(\Delta \mathrm{pO}_{2}\right)$ during moderate to severe fetal hypoxemia.

Ninety seconds after the start of acute UBF decrease $\mathrm{pO}_{2}$ in the umbilical artery had fallen (Range 0 to 13 Torr, Mean 6.45, SD \pm 4.5 Torr). A statistically 


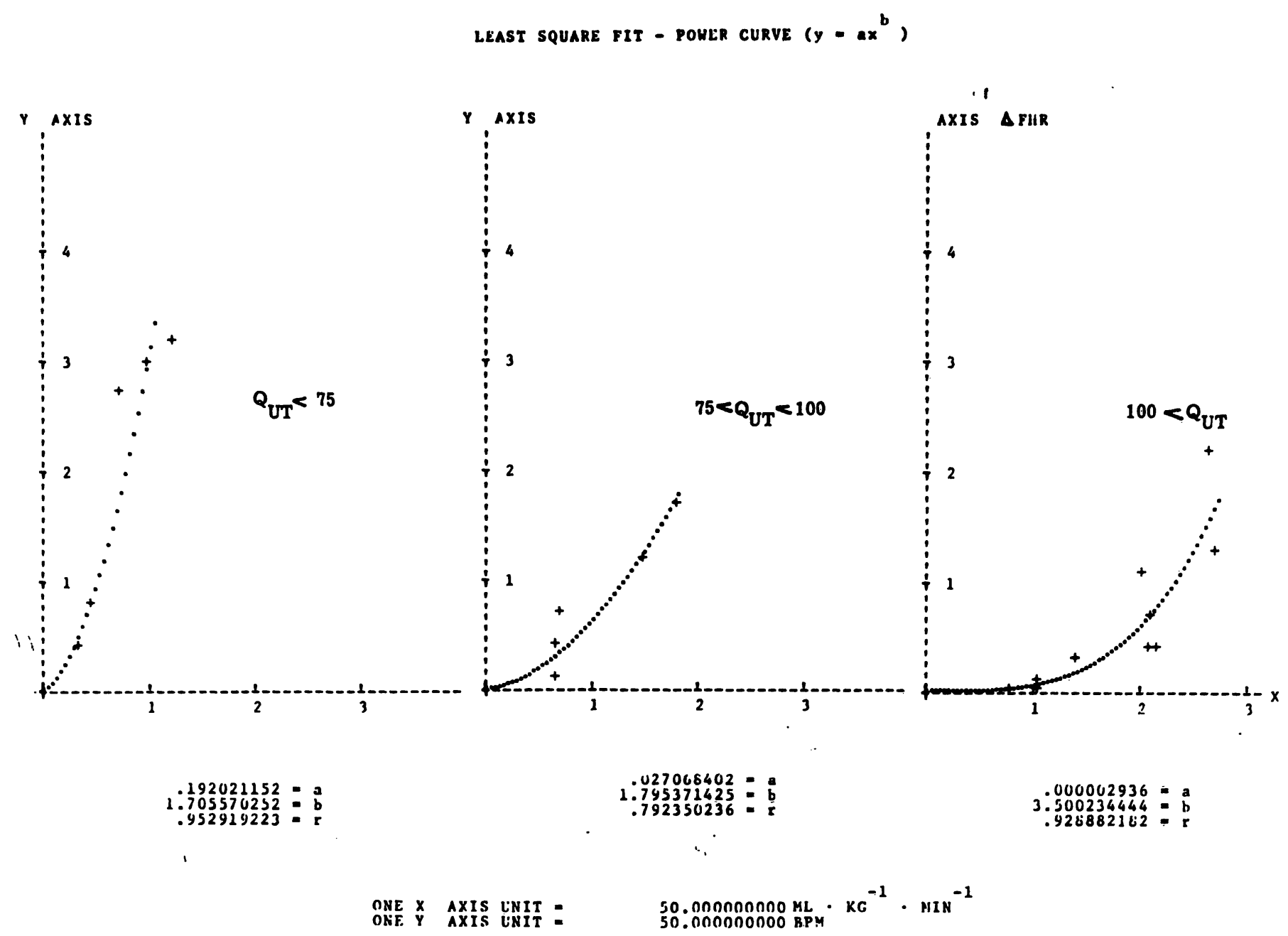

Fig. 11. Relationship between absolute values of $\triangle F H R$ and $\Delta Q_{U T}$ for physiologic (graph on the right), prepathologic (graph in the center) and pathologic (graph on the left) levels of bașal UBF. Significant alinear correlation for $\Delta F H R$ versus $\Delta$ QUT and basal QUT $>100 \mathrm{ml} / \mathrm{kg} / \mathrm{min}$. Alinearity not significant for basal QUT $<100 \mathrm{ml} / \mathrm{kg} / \mathrm{min}$, but the slope of regression is rising with falling basal QUT.

highly significant linear correlation exists between decrease of UBF and decrease of $\mathrm{pO}_{2}(\mathrm{r}=.80$, $2 \alpha<.001$ ) (Fig. 13). The regression may be approximated by $\Delta \mathrm{pO}_{2}=.1 \Delta \mathrm{QUT}_{\mathrm{UT}}$, i.e. a UBF reduction of $50 \mathrm{ml} / \mathrm{kg} / \mathrm{min}$ will on an average lead to a $\mathrm{pO}_{2}$ decrease of 5 Torr.

2.4.2 Relationship between acute fall of $\mathrm{pO}_{2}$ in the umbilical artery $\left(\Delta \mathrm{pO}_{2}\right)$ and FHR decrease ( $\triangle$ FHR), the deceleration amplitude.

Correlation between $\Delta \mathrm{QuT}_{\mathrm{UT}}$ and $\Delta \mathrm{pO}_{2}$ being linear and highly significant the same relation between $\Delta \mathrm{FHR}$ and $\Delta \mathrm{pO}_{2}$ should be expected as between $\triangle F H R$ and $\Delta$ QUT. This holds true in general: a significant correlation between the $\Delta \mathrm{FHR} / \Delta \mathrm{pO}_{2}$ ratio on basal FHR can be seen, but the $\triangle F H R /$
$\Delta \mathrm{pO}_{2}$ ratio is not well correlated to bas $\mathrm{pO}_{2}$ and alinearity for the regression of $\triangle \mathrm{FHR}$ on $\Delta \mathrm{pO}_{2}$ in the normal FHR range could not be verified statistically. A linear regression was found significant for this range as well as for the range of severe tachycardia. For moderate tachycardia no significant correlation could be verified (Figs. 14-17).

2.5 Lag time of UBF reduction induced FHR fall A histogram of lag times between the onset of UBF reduction and onset of FHR fall is shown in Fig. 18. It can be seen that the lag time was less than $11 \mathrm{sec}$ in about $40 \%$ and less than $21 \mathrm{sec}$ in about $80 \%$. A correlation between basal FHR level and lag time could not be verified. 
LEAST SQUARE FIT - POHER CURVE $\left(y-a x^{2}\right)$
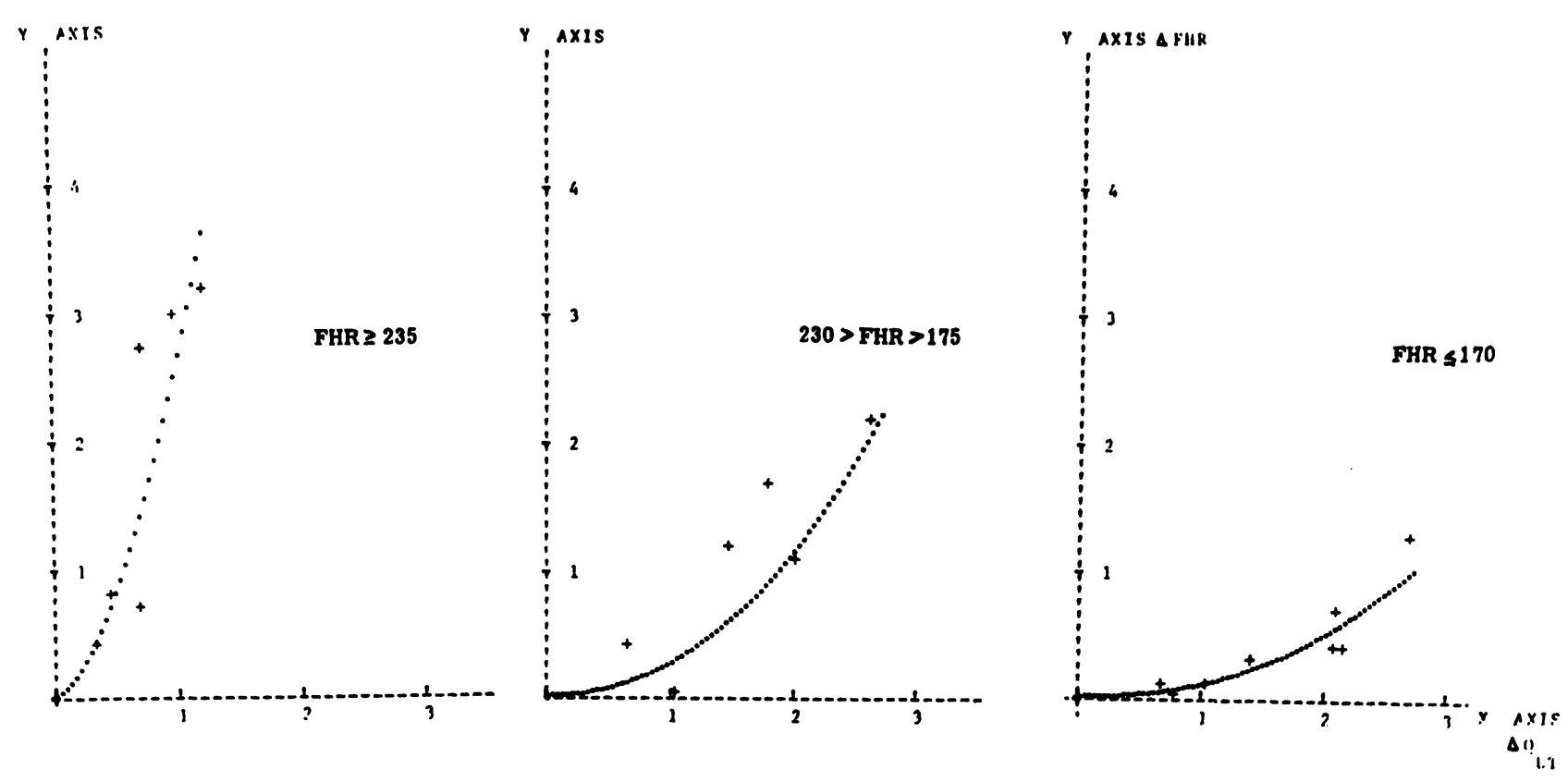

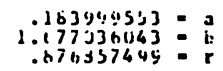

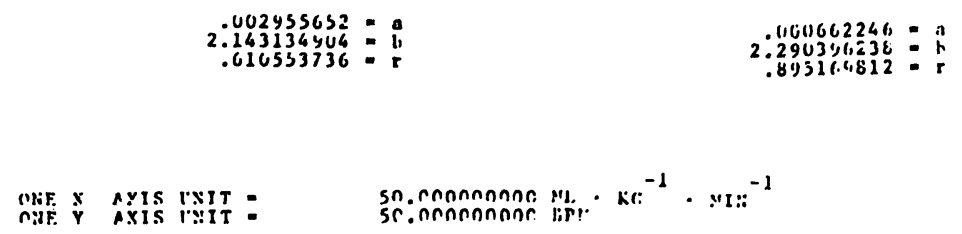

Fig. 12. Relationship between absolute values of $\triangle F H R$ and $\triangle Q U T$ for various levels of basal FHR. The slope of regression is rising with rising level of basal FHR.

\section{Discussion}

All obstetricians practicing FHR monitoring are confronted with the problems of correct interpretation of FHR recordings. A late deceleration pattern is commonly taken as a sign of developing fetal distress and severeness of decelerations and fetal distress is judged in part from deceleration amplitudes. But there is little information about factors influencing deceleration amplitude. AsSALI and coworkers [3] published data on the relationship between reduction of UBF and FHR decrease. Our present data give additional knowledge concerning the influence of basal UBF and basal FHR and the role of the UBF reduction induced fall of fetal $\mathrm{pO}_{2}$, which is supposed to mediate the fall of FHR.
First of all a discussion of the time courses of UBF, $\mathrm{pO}_{2}$ and $\mathrm{pH}$ in the umbilical artery and of FHR in connection with repetitive acute reduction of aortic flow and hence UBF is worth while (Fig. 4).

3.1 UBF dropped rapidly on reducing blood flow in the lower aorta of the ewe. On deflation of the obstructing balloon catheter UBF rose as rapidly again, but on $50 \%$ to $100 \%$ reduction this rise was sometimes followed by a slight rebound fall that gradually faded out. This phenomenon will be discussed on below.

3.2 Mean $\mathrm{pO}_{2}$ in the umbilical artery - initially in the moderate to severe hypoxemic level - fell rapidly and proportionally to the amount of UBF 


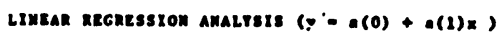

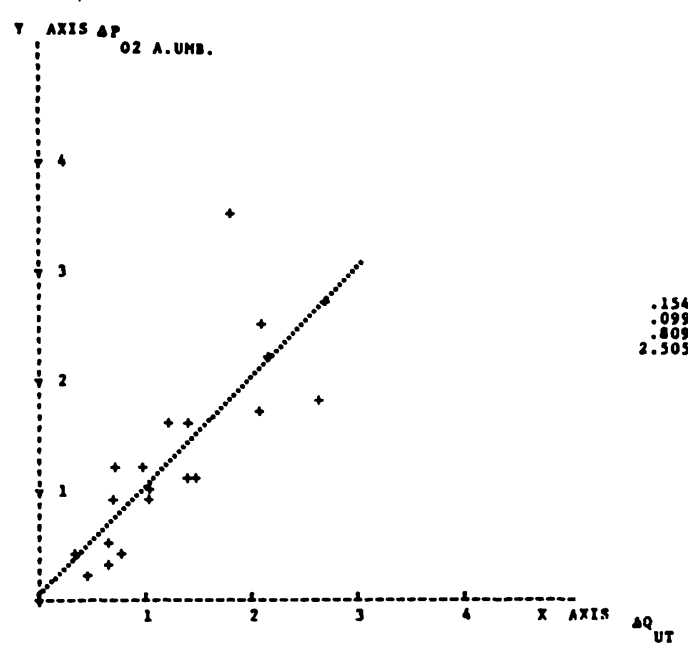

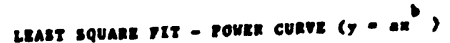

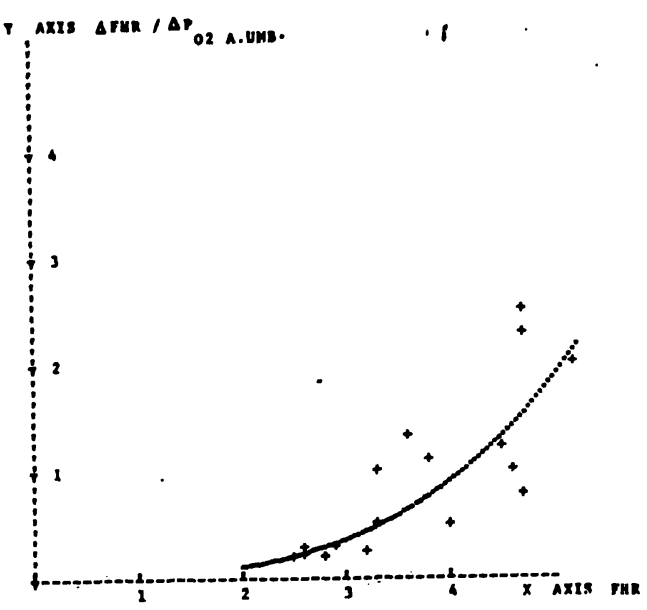

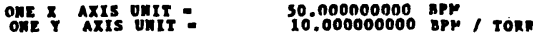

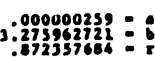

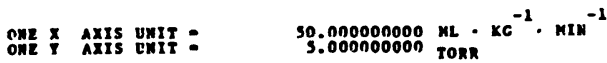

N 20

2a $<$.ons

Fig. 13
Fig. 15

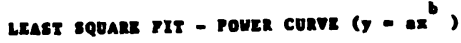

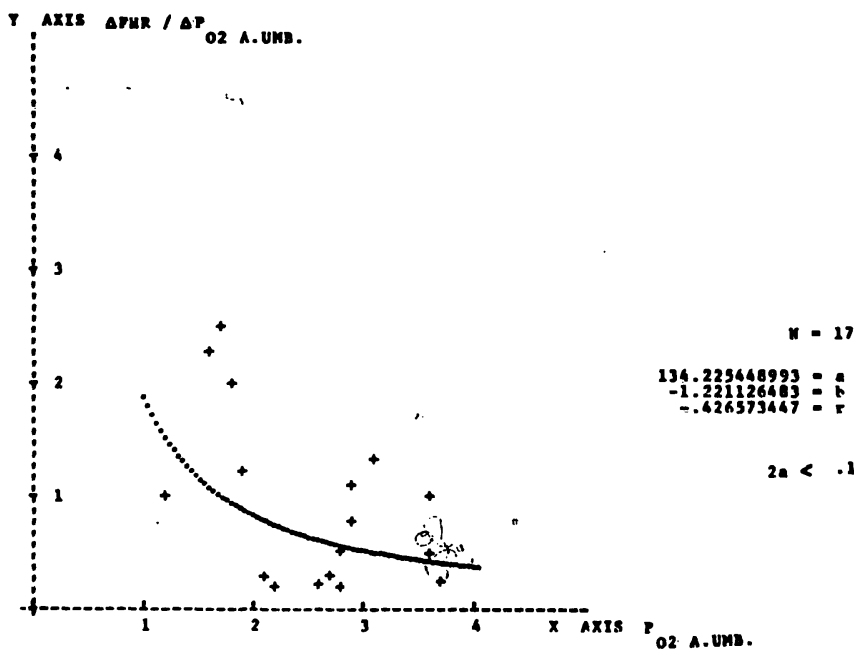

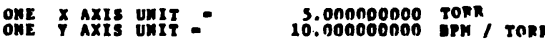

Fig. 14

Fig. 16

Fig. 13. Significant linear correlation between absolute values of $\Delta \mathrm{pO}_{2}$ in the umbilical artery and $\Delta Q U T$ during moderate to severe hypoxemia. (Basal $\mathrm{pO}_{2}<20$ Torr).

Fig. 14. Significant correlation between $\triangle F H R$ and $\Delta \mathrm{pO}_{2}$ in the umbilical artery, both taken as percentage of basal values. (See also legend to Fig. 8).

Fig. 15. Significant correlation between $\Delta \mathrm{FHR} / \Delta \mathrm{pO}_{2}$ ratio and basal FHR. Deceleration amplitude per unit of $\mathrm{pO} 2$ decrease rises with rising basal FHR.

Fig. 16. Relationship between $\Delta \mathrm{FHR} / \Delta \mathrm{pO}_{2}$ ratio and basal $\mathrm{pO}_{2}$. Correlation nearly significant. Deceleration amplitude per unit of $\mathrm{pO}_{2}$ decrease rises with falling basal $\mathrm{pO}_{2}$. 


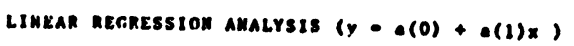
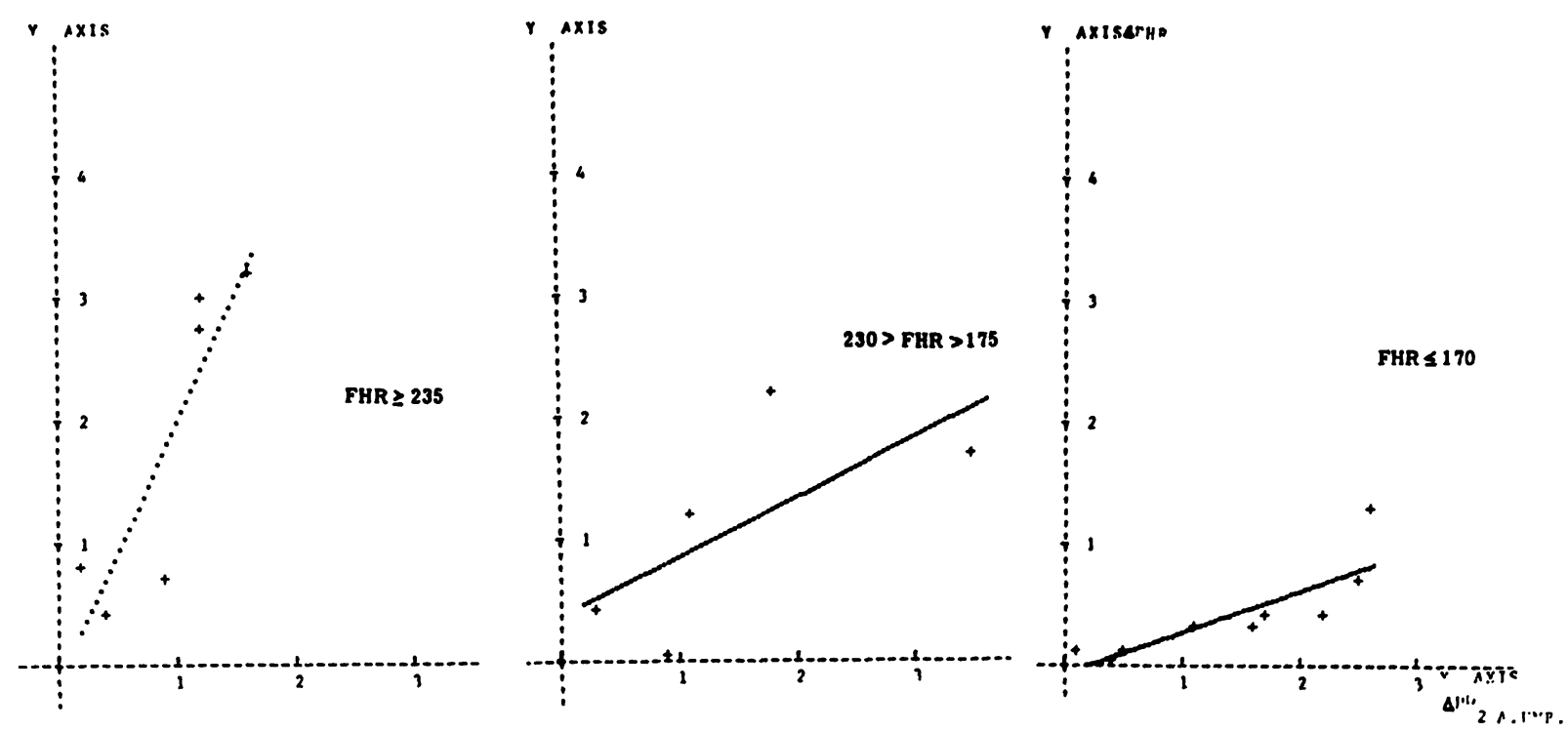

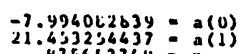

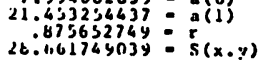

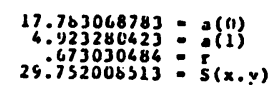

$\begin{array}{r}-4.050463880 \\ 3: 50451731\end{array}:$ (1)

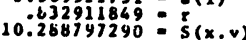

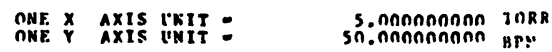

Fig. 17. Relationship between absolute values of $\Delta \mathrm{FHR}$ and $\Delta \mathrm{pO}_{2}$ for various levels of basal FHR. The slope of regression is rising with rising level of basal FHR.

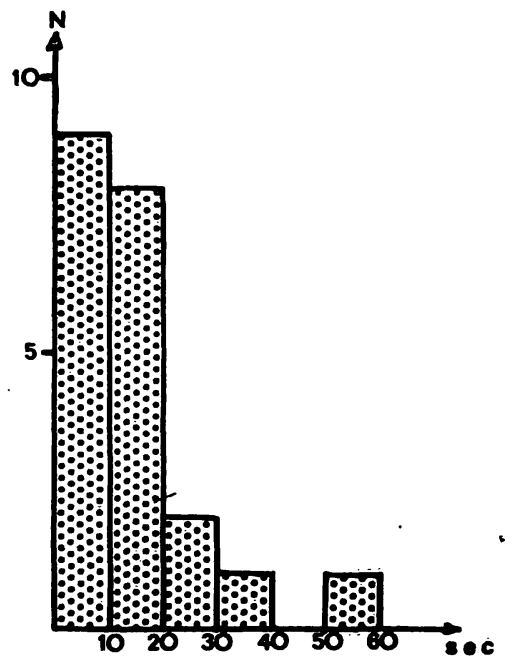

Fig. 18. Histogram of lag times between onset of UBF reduction and onset of FHR deceleration. reduction. Ten min after the end of each reduction, but presumably much earlier mean $\mathrm{pO}_{2}$ was in the initial range again. That means changes occur with a short time constant. Publications on continuous monitoring of $\mathrm{pO}_{2}$ support this fact $[14,16,24$, $29,30]$ though absolute data for the time constant are missing.

3.3 Mean $\mathrm{pH}$ decreased proportionally during reduction of $\mathrm{UBF}$. In contrast to $\mathrm{pO}_{2} 10 \mathrm{~min}$ after the end of the reduction phase the fetus had not recovered in respect to $\mathrm{pH}$. In fact $\mathrm{pH}$ remained constantly lowered or even a slight further decrease could be seen. Our explanation for this phenomenon is the following:

Hypoxemia from UBF reduction leads to fetal cardiovascular reaction with redistribution of fetal 
circulation $[4,7,10,11,12,20,25]$. The initial rapid fall of $\mathrm{pH}$ during $\mathrm{UBF}$ reduction may be caused by hypercapnia and by an immediate lactat input from regions of fetal circulation with unchanged perfusion during hypoxemic fetal cardiovascular reaction. This component of lactat input has a short time constant and gives rise to the initial rapid $\mathrm{pH}$ fall. The secondary decrease of $\mathrm{pH}$ after cessation of UBF reduction may be the resultant of a delayed lactat input from regions of fetal circulation with diminished perfusion during hypoxemic redistribution, when these regions are reopened again on one side and overall lactat elimination on the other side.

Different time courses in the restitution from hypoxemia and acidosis after contraction elicited UBF reduction may explain well known findings taken from the dilatation phase of labors, for which a slight progressive fall of mean $\mathrm{pH}$ could be found despite a seemingly constant normal mean $\mathrm{pO}_{2}$, especially when blood sampling is performed in the late phase of uterine relaxation. On the other hand, in the expulsion period a $\mathrm{pO}_{2}$ fall along with a further fall of $\mathrm{pH}$ is seen $[5,13,26,34]$ despite of the short $\mathrm{PO}_{2}$ time constant, because contractions become stronger and relaxation phase shortens.

3.4 Several items have to be discussed in regard to FHR changes. (It may be necessary to point out the fact again, that there was moderate to severe hypoxemia during the experimental sequences).

3.4.1 Mean FHR changes (Fig. 4) resembled the changes of UBF and $\mathrm{pO}_{2}$, but $10 \mathrm{~min}$ after the end of the UBF reduction sequence mean basal FHR was slightly elevated and the explanation may be compensatory tachycardia.

3.4.2 The slopes of FHR descents and ascents varied. In general changes were more rapid when basal FHR was high and when UBF reduction was about $50 \%$ to $100 \%$. On several occasions after UBF reduction of larger amount a secondary deceleration could be seen together with the secondary fall of UBF mentioned above (see Figs. 3 and Figs. 19). A biphasic deceleration like this by the way quite often can be seen in clinical FHR monitoring. The reason for this phenomenon is not quite clear. It might be a simultaneous rise in fetal blood pressure because injection of epinephrine directly into the fetal buttock elicited a blood pressure rise and UBF decrease as well as FHR fall (Fig. 19, right column).

3.4.3 Evaluation of relations between UBF reduction and FHR decrease (Fig. 7) was disappointing at first glance. The key to understanding was the fact that there is an alinear correlation between relative values only when $100 \mathrm{bpm}$ (the lowestheartrateseen with complete UBF reduction) is taken as $\phi \%$. And this correlation of relative values points to the fact that there is a dependency from basal UBF and FHR values. This dependency can be seen clearly in Figs. 9 and 10.

According to others and own results $[17,18,22]$ the borderline to pathologic uterine blood flow near term seems to be in the range of about $100 \mathrm{ml} / \mathrm{kg} / \mathrm{min}$ in various species. In fact, uterine $\mathrm{O}_{2}$ uptake is reduced when UBf falls below 80$100 \mathrm{ml} / \mathrm{kg} / \mathrm{min}$. These findings are paralleled by our results in so far as the $\Delta F H R / \Delta Q_{U T}$ ratio is constantly low and independent of basal UBF and basal FHR as long as basal UBF is above this borderline and that this ratio increases sharply when UBF falls well below it. The same holds true for basal FHR but in the opposite direction because of the inverse relationship between basal UBF and basal FHR: there is a definite increase of the $\Delta \mathrm{FHR} / \Delta \mathrm{Q}_{\mathrm{UT}}$ ratio when basal FHR is elevated to its maximum.

Figs. 11 and 12 give further information. Looking at the graphs for physiologic ranges of UBF and FHR (the graphs on the right sides) separately, it can be seen that in this range $\Delta F H R / \Delta Q_{U T}$ is a function of $\Delta Q_{U T}$ itself: UBF reduction up $50 \mathrm{ml} /$ $\mathrm{kg} / \mathrm{min}$ does not affect FHR at all. Only submaximal to complete reduction leads to minor decelerations. On the other hand, with falling UBF levels (and increasing FHR levels) the sole functional influence of $\Delta Q_{U T}$ is diminishing and the influence of basal UBF and basal FHR is getting into play (Figs. 11 and 12, graphs in the center and on the left).

3.4.4 Evaluation of our data verified a highly significant correlation between $\mathrm{pO}_{2}$ decrease and UBF reduction for basal $\mathrm{pO}_{2}<20$ Torr (Fig. 13). From this it is not surprising that the relationship between $\triangle \mathrm{FHR}$ and $\Delta \mathrm{pO}_{2}$ to. a large extent 

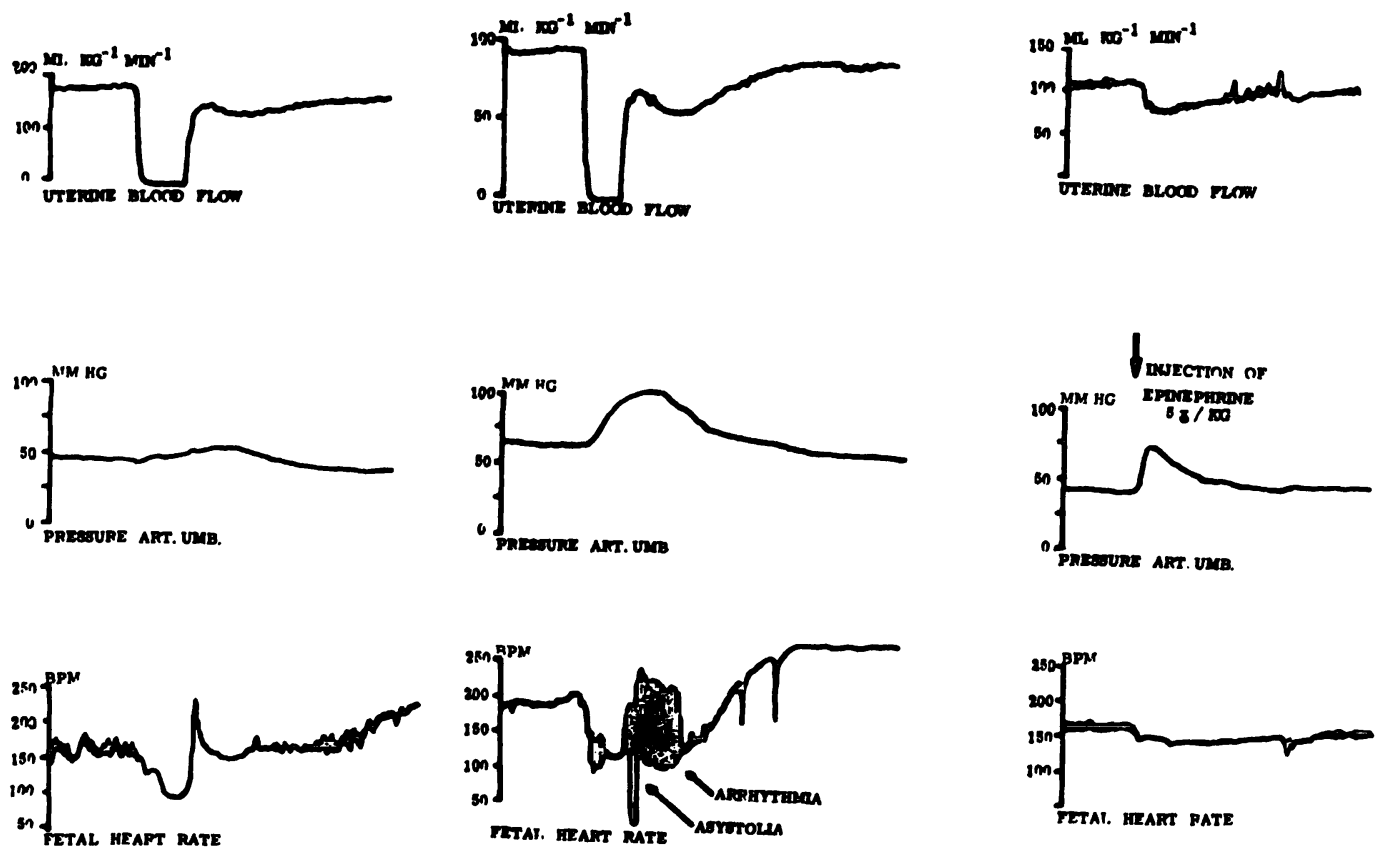

Fig. 19. Recordings of UBF (above), umbilical arterial pressure (middle) and FHR (below). Reaction of pressure and FHR on acute reduction of UBF.

A secondary fall of FHR and UBF after the end of acute UBF reduction can be seen simultaneusly with the rise in arterial pressure. (Graphs on the left and in the center). The latter may be the cause of secondary UBF and FHR reaction. Rise of arterial pressure after injection of epinephrine direct into the fetal buttock is accompanied by a fall in UBF and FHR. (Graph on the right).

resembles the relationship of $\Delta \mathrm{FHR}$ and $\Delta \mathrm{Q}_{\mathrm{UT}}$. Statistics though give poorer results (Figs. 14-17). This may be explained by the short time constant of $\mathrm{pO}_{2}$ giving rise to more overall variation in $\mathrm{pO}_{2}$ data. On the other hand one has to take in mind that progressive $\mathrm{pH}$ decrease caused a shift in the oxygen dissociation graph during the course of the experiment.

3.4.5 Our present data lead to the conclusion that no single parameter being analysed is responsible for FHR alterations solely. FHR response, i.e. deceleration amplitude is modified by basal values of UBF, fetal $\mathrm{pO}_{2}$ and FHR and by the amount and slope of $\mathrm{UBF}$ reduction and consecutive $\mathrm{pO}_{2}$ decrease. Thus the most extensive deceleration amplitudes were seen when all parameters were adversely al tered. That the state of fetal oxygenation and its acute changes have a major influence on the shape of FHR alterations has been shown by others $[21,27]$. On the other hand one may argue that the level of basal FHR modifies deceleration amplitude too haging in mind WILDER's "Law of Initial Value" [31, 32], which in parallel has been adopted for defining heart rate regulation in the newborn $[19,28]$.

3.4.6 The lag time between the onset of UBF reduction and the onset of FHR deceleration turned out to be less than $11 \mathrm{sec}$ in about $40 \%$ and less than $21 \mathrm{sec}$ in $80 \%$ (Fig. 18). Although our results are taken from fetuses of ewes ingeneral anaesthesia, they may hint to the fact that in severe hypoxemia the lag time may shorten. In fact a significant shortening of lag time with decrease of fetal arterial oxygen saturation and oxygen tension has been reported [21]. 


\section{Summary}

Five merino sheep near term were used for acute preparations to investigate the influence of basal uterine blood flow (UBF), basal fetal oxygenation and basal fetal heart rate (FHR) on FHR changes elicited by acute reduction of UBF.

The ewes were anaesthesized with pentobarbital and Alloferin was given for relaxation. Ventilation was maintained via a tracheal tube by a Starling pump. Maternal heart rate, arterial pressure and intrauterine pressure as well as fetal heart rate and umbilical artery pressure were recorded continously. Initially blood flow was recorded by cuff flow meter sequentially in both uterine arteries for a short time in order to determine total UBF and the ratio of flows. During the UBF reduction sequence flow was recorded in the artery of the gravid horn continously and measurement was corrected according to the initial ratio of flows in both arteries, presuming that this ratio would remain constant throughout the course of the experiment.

Repetitive and progressive acute reduction of UBF (approximately 25\%, 50\% and 100\% from basal UBF value) was achieved three times, lasting $120 \mathrm{sec}$ each and each approximatly $12 \mathrm{~min}$ apart, by flow meter controlled partial or total occlusion of the aorta abdominalis of the ewe with a balloon catheter inserted into the aorta. (In some cases the lateral abdominal section was left open and the aorta was compressed manually).

Before, $90 \mathrm{sec}$ after the beginning and $10 \mathrm{~min}$ after the end of UBF reduction blood samples were taken from the fetal catheters (Fig. 3). In two preparations this sequence was repeated once after complete recovery of FHR.

\section{Results}

Initial UBF values ranged from 180 to $57 \mathrm{ml} / \mathrm{kg} / \mathrm{min}$, $\mathrm{pO}_{2}$ in the umbilical artery was 18.5 to 6 Torr, $\mathrm{pCO}_{2}$ was 37 to 57 Torr and pH 7.43 to $7.23 \mathrm{pH}$ units. Basal FHR ranged from 130 to $235 \mathrm{bpm}$. Thus wide ranges of UBF as well as fetal cardiovascular and biochemical situations were under investigation. Altogether low basal UBF was accompanied by fetal hypoxemia and tachycardia. The time courses of $\mathrm{UBF}, \mathrm{pO}_{2}, \mathrm{pCO}_{2}$ and $\mathrm{pH}$ in the umbilical artery and of FHR in connection with repetitive acute reduction of aortic flow were the following:

UBF dropped rapidly on reducing aortic blood flow. On release of the aortic obstruction it rose as rapidly again, but on $50 \%$ to $100 \%$ reduction this rise was sometimes followed by a slight rebound fall that gradually faded out. Mean $\mathrm{pO}_{2}$ in the umbilical artery, initially in the moderate to severe hypoxemic level, fell rapidly and proportionally to the amount of UBF reduction. Ten minutes after the end of each reduction, but presumably much earlier mean $\mathrm{pO}_{2}$ was in the initial range again. Mean $\mathrm{pH}$ decreased proportionally during reduction of UBF. In contrast to $\mathrm{pO}_{2} 10 \mathrm{~min}$ after the end of the reduction phase the fetus had not recovered in respect to $\mathrm{pH}$. In fact, $\mathrm{pH}$ remained lowered or even a slight further decrease could be seen. Mean FHR changes resembled the changes of UBF and $\mathrm{pO}_{2}$, but $10 \mathrm{~min}$ after the whole UBF reduction sequence mean basal FHR was slightly elevated.

As to the relationship between acute reduction of UBF $(\Delta Q U T)$ and FHR decrease $(\Delta F H R)$ an alinear correlation between the values, expressed as percentage of basal level, could be verified. This fact leads to the conclusion that the $\Delta F H R / \triangle Q U T$ ratio is dependent on basal values of UBF and FHR: statistics reveal that within physiologic levels of UBF and FHR minor and moderate acute UBF reductions do not affect FHR at all or lead to minor decelerations. Only substantial reductions will cause decelerations of larger amplitude. But with decreasing basal UBF levels (and increasing FHR levels) the same absolute amount of UBF reduction leads to increasing deceleration amplitudes.

As it is widely accepted that FHR decelerations caused by acute $\mathrm{UBF}$ reduction are mediated by a fall in fetal $\mathrm{pO}_{2}$, the relations between acute UBF reduction and $\mathrm{pO}_{2}$ fall in the umbilical artery were investigated and a highly significant linear correlation could be found. Therefore the same relations between $\triangle F H R$ and $\Delta \mathrm{pO}_{2}$ should be expected as between $\triangle F H R$ and $\Delta Q U T$. This holds true in general but statistics give poorer results, probably because the short time constant of $\mathrm{pO}_{2}$ gives rise to more overall variation in $\mathrm{pO}_{2}$ data. On the other hand one has to take in mind that progressive $\mathrm{pH}$ decrease caused a shift in the oxygen dissociation graph during the course of the experiment.

The lag time between on'set of UBF reduction and onset of FHR deceleration was less than $11 \mathrm{sec}$ in about $40 \%$ and less than $21 \mathrm{sec}$ in $80 \%$.

Keywords: Acidosis, animal experiments, cardiotocography, deceleration, heart rate, fetus, hypoxemia, lag time, uterine blood flow

\section{Zusammenfassung}

Akute Verminderung der Uterusdurchblutung und Veränderungen der fetalen Herzfrequenz beim Schaf am Ende der Tragzeit.

Es sollte der Einfluß der basalen Uterusdurchblutung, der basalen fetalen Oxygenation und der basalen fetalen Herzfrequenz auf die durch akute Drosselung der Uterusdurchblutung hervorgerufenen fetalen Herzfrequenzveränderungen untersucht werden. Dazu wurden 5 hoch- trächtige Merinoschafe mit Pentobarbital narkotisiert und mit Alloferin relaxiert. Die Ventilation wurde nach Tracheotomie und Intubation mit einer Starling-Pumpe aufrechterhalten. Die materne Herzfrequenz, der materne arterielle Druck, der Intrauterindruck, die fetale Herzfrequenz, der Druck in der Arteria umbilicalis wurden kontinuierlich registriert. Vor der eigentlichen Versuchsdurchführung wurde die Durchblutung mit einem Cuff- 
flowmeter hintereinander kurzzeitig in beiden Uterinarterien gemessen und die Gesamtuterusdurchblutung sowie das Verhältnis beider bestimmt. Während des Drosselungsversuches wurde die Durchblutung auf der Seite des graviden Horns kontinuierlich registriert und die Eichskala entsprechend dem Durchblutungsverhältnis in beiden Arterien auf die Gesamtdurchblutung korrigiert. Eine wiederholte und jeweils zunehmende Drosselung der Uterusdurchblutung (nährungsweise $25 \%, 50 \%$ und $100 \%$ vom Ausgangswert der Durchblutung) von jeweils $120 \mathrm{sec}$ Dauer und etwa im Abstand von $12 \mathrm{~min}$ wurde durch partielle oder totale Verlegung der Aorta abdominalis des Muttertieres mit einem Ballonkatheter erreicht. (In einigen Fällen blieb die Laparotomiewunde offen und die Aorta wurde manuell komprimiert). Vor, $90 \mathrm{sec}$ nach Beginn und $10 \mathrm{~min}$ nach Ende der Durchblutungsdrosselung wurden Blutproben zur Bestimmung von $\mathrm{PO}_{2}, \mathrm{PCO}_{2}$ und pH aus dem in einem Ast der Arteria umbilicalis liegenden Katheter entnommen. Bei 2 Schafen wurde die Drosselungssequenz nach Stabilisierung der fetalen Herzfrequenz wiederholt.

\section{Ergebnisse}

Die Ausgangswerte für die Uterusdurchblutung lagen zwischen 180 und $57 \mathrm{ml} / \mathrm{kg} / \mathrm{min}$, der $\mathrm{pO}_{2}$ in der Arteria umbilicalis wurde mit 18,5 bis 6 Torr, der $\mathrm{pCO}_{2}$ mit 37 bis 57 Torr und pH mit 7,43 bis 7,23 pH-Einheiten bestimmt. Das fetale basale Herzfrequenzniveau lag zwischen 130 und 235 Spm. Damit kamen also weite Bereiche basaler Uterusdurchblutung und fetaler kardiovaskulärer und biochemischer Situationen zur Auswertung. Insgesamt fand sich bei erniedrigter Uterusausgangsdurchblutung eine Tendenz $\mathrm{zu}$ fetaler Hypoxämie und Tachykardie.

Die Zeitgänge von Uterusdurchblutung, $\mathrm{pO}_{2}, \mathrm{pCO}_{2}$ und $\mathrm{pH}$ in der Arteria umbilicalis sowie der fetalen Herzfrequenz bei akuter und wiederholter Aortendurchblutungsdrosselung waren folgende: es kam zum steilen Abfall der Uterusdurchblutung. Nach Beendigung der Aortenkompression stieg die Uterusdurchblutung ebenso steil wieder an. Bei 50 bis $100 \%$ iger Drosselung jedoch folgte diesem Wiederanstieg gelegentlich ein leichter Wiederabfall, der dann langsam abklang. Der $\mathrm{pO}_{2}$-Mittelwert in der Arteria umbilicalis, schon vor der Drosselungssequenz im Bereich mittlerer bis schwerer Hypoxämie, fiel steil und proportional zum Ausmaß der Uterusdurchblutungsdrosselung. $10 \mathrm{~min}$ nach Ende jeder Drosselung, wahrscheinlich aber viel früher, fand sich der $\mathrm{pO}_{2}$-Mittelwert wieder im Ausgangsbereich. Der pH-Mittelwert fiel während der Drosselung proportional ab. Im Gegensatz zum $\mathrm{pO}_{2}$ hatte sich der Fet 10 min nach Ende der Drosselung in Bezug auf den pH-Wert aber noch nicht erholt: der pH-Wert blieb vielmehr erniedrigt, bzw. es wurde sogar ein weiterer pHAbfall beobachtet. Der Mittelwert der fetalen Herzfrequenz verhielt sich analog den Veränderungen der Uterusdurchblutung und dem $\mathrm{pO}_{2}$, allerdings fand sich $10 \mathrm{~min}$ nach Ende der Drosselungssequenz eine leichte Frequenzerhöhung.

Es gelang der Nachweis einer alinearen Korrelation zwischen den prozentualen Werten der akuten Uterusdurchblutungsdrosselung und der Herzfrequenzdezeleration. Das deutet darauf hin, daß das Verhältnis $\triangle F H R /$ $\Delta Q_{U T}$ von den Ausgangswerten der Uterusdurchblutung und der fetalen Herzfrequenz abhängig ist. Die weitere statistische Aufarbeitung zeigt, daß im Bereich physiologischer Uterusdurchblutung und fetaler Herzfrequenz leichte und mittlere Drosselungen der Uterusdurchblutung die Herzfrequenz nicht beeinflussen, allenfalls minimale Dezelerationen hervorrufen und nur erhebliche Durchblutungsdrosselungen zu Dezelerationen größerer Amplitude führen. Mit sinkender Ausgangsuterusdurchblutung (oder steigender fetaler Herzfrequenz) erzeugt die gleiche absolute Durchblutungsdrosselung jedoch Dezelerationen zunehmender Amplitude.

Weil angenommen wird, daß die durch Uterusdurchblutungsdrosselung bedingten Dezelerationen durch einen $\mathrm{pO}_{2}$-Abfall hervorgerufen werden, wurden auch die Beziehungen zwischen der Uterusdurchblutungsdrosselung und dem $\mathrm{pO}_{2}$-Abfall in der Arteria umbilicalis untersucht. Dabei fand sich ein hoch signifikant linearer Zusammenhang. Deshalb sollten zwischen dem $\mathrm{pO}_{2}-\mathrm{Ab}-$ fall und der Dezelerationsamplitude die selben quantitativen Beziehungen bestehen wie zwischen der Uterusdurchblutungsdrosselung und der Dezelerationsamplitude. Das ließ sich im vorliegenden Datenmaterial in der Tendenz auch nachweisen, doch waren die statistischen Ergebnisse nicht so eindeutig. Möglicherweise führt die kurze Zeitkonstante des $\mathrm{pO}_{2} \mathrm{zu}$ mehr Variationen bei den $\mathrm{pO}_{2}$ Daten. Andererseits muß bedacht werden, daß der zunehmende pH-Abfall während der Dauer des Experiments eine Verschiebung der $\mathrm{O}_{2}$-Dissoziations-Kurve erzeugte.

Die Verzögerungszeit zwischen dem Beginn der Uterusdurchblutungsdrosselung und dem Beginn der Dezeleration lag in etwa $40 \%$ unter $11 \mathrm{sec}$ und in $80 \%$ unter $21 \mathrm{sec}$.

Schlüsselwörter: Azidose, CTG, Dezeleration, Durchblutung (uterim), Fet, Herzfrequenz (fetale), Hypoxämie, Tierversuch, Verzögerungszeit.

\section{Résumé}

Jugulation de la circulation du sang dàns l'uterus et alterations du rhythme cardiaque foetal chez les brebis enceintes approchant du terme

L'article présent traite de l'influence de la circulation sanguine utérine de base, de l'oxygénation et de la fréquence cardiaque basales du foetus sur les altérations du rhythme cardiaque foetal résultant d'une jugulation aigue de la circulation utérine. A cet effet, on a administré à 5 brebis mérinos en stade avancé de grossesse une narcose de pentobarbital et un relaxant d'alloférine. La ventilation a été maintenue après trachéotomie et intubation avec une pompe Starling. La fréquence cardiaque et la pression artérielle de la mère, la pression intrautérine, la fréquence cardiaque du foetus, la pression dans l'artère ombilicale 
ont été enregistrées de façon continue. Avant de procéder à l'examen proprement dit, on a utilisé un Cuff-flow meter pour mesurer à brefs intervalles la circulation sanguine dans les deux artères utérines, ce qui a permis d'observer l'ensemble de la circulation utérine et le rapport entre la circulation des deux artères. Durant toute la séquence de jugulation on a enregistré de façon continue la circulation dans l'artère de la corne gravide et corrigé les mesures en accord avec le rapport initial entre la circulation des deux artères, ce rapport étant supposé constant tout au long de l'expérimentation. Une jugulation aigue de la circulation sanguine dans l'utérus, progressive et répétée trois fois (environ $25 \%, 50 \%$ et $100 \%$ de la valeur de base de la circulation utérine), d'une durée respective de $120 \mathrm{sec}$. et à intervalles approximatifs de 12 min', a été effectuée par occlusion partielle ou totale de l'aorte abdominale de la femelle mère à l'aide d'un cathéter à ballon. (Dans quelques cas, l'ouverture de la la parotomie a été maintenue béante pour permettre la compression manuelle de l'aorte). Avant la jugulation sanguine, $90 \mathrm{sec}$. après son début et $10 \mathrm{~min}$. après sa fin, du sang a été prélevé dans le cathéter placé dans le cathéter placé dans une branche de l'artère ombilicale pour définir le $\mathrm{pO}_{2}$, le $\mathrm{pCO}_{2}$ et le $\mathrm{pH}$. Chez 2 brebis, la séquence de jugulation a été répétée après stabilisation complète de la fréquence cardiaque du foetus.

\section{Résultats:}

Les valeurs initiales de la circulation sanguine utérine se sont situées entre 180 et $57 \mathrm{ml} / \mathrm{kg} / \mathrm{min} ; 1$ le $\mathrm{pO}_{2}$ de l'artère ombilicale a varié entre 18,5 et 6 Torr, le $\mathrm{pCO}_{2}$ entre 37 et 57 Torr et le pH entre 7,43 et 7,23 unités pH. Le niveau initial de fréquence cardiaque du foetus se situa entre 130 et $235 \mathrm{bpm}$ (battement $/ \mathrm{min}$ ). C'est ainsi qu'on a pu évaluer également des problèmes assez vastes de la circulation sanguine utérine basale et des situations cardio-vasculaires et biochimiques chez le foetus. Dans l'ensemble. on observa une tendance à l'hy poxémie et tachycardie foetales dans les cas d'un niveau bas de circulation utérine initiale.

Les temps de circulation sanguine utérine, de $\mathrm{pO}_{2}, \mathrm{pCO}_{2}$ et $\mathrm{pH}$ dans l'artère ombilicale ainsi que de la fréquence cardiaque foetale en cas de jugulation aigue et répétée de la circulation aortique ont été les suivants: baisse rapide de la circulation utérine qui a remonté aussi rapidement une fois cessée la compression aortique. Mais dans les jugulations de 50 à $100 \%$, cette remontée a été occasionnellement suivie d'une légère rechute qui s'atténua peu à peu. La moyenne du $\mathrm{pO}_{2}$ dans l.artẻre ombilicale, qui se situait initialement au niveau d'hypoxémie modérée à grave, baissa brusquement et de façon proportionnelle à l'importance de la jugulation de la circulation utérine. $10 \mathrm{~min}$ après chaque jugulation, mais probablement beaucoup plus tôt, la moyenne du $\mathrm{pO}_{2}$ retrouvait à peu près son niveau de départ.

La moyenne du $\mathrm{pH}$ baissa de façon proportionnelle pendant la jugulation. En ce qui concerne le pH et au contraire du $\mathrm{pO}_{2}$, le foetus n’agait pas encore récupéré $10 \mathrm{~min}$ après l'arrêt de la jugulation: en effet, la valeur du pH resta plutôt basse et subit même occasionnellement une nouvelle et légère chute. La moyenne de la fréquence cardiaque du foetus se comporta de façon analogue aux modifications de la circulation utérine et au $\mathrm{pO}_{2}$; mais on observa une légère hausse de la fréquence initiale moyenne $10 \mathrm{~min}$ après la fin de la séquence de jugulation.

On a pu vérifier une corrélation alinéaire entre les valeurs exprimées en pourcentage du niveau initial relatives à la jugulation aigue de la circulation utérine ( $\triangle Q U T)$ et à la décélération de la fréquence cardiaque $(\Delta F H R)$. D'où on peut conclure que le rapport $\Delta F H R / \Delta Q_{U T}$ dépend des valeurs initiales de la circulation sanguine utérine et de la fréquence cardiaque du foetus: Les évaluations statistiques montrent qu'en ce qui concerne la circulazion utérine physiologique et la fréquence cardiaque foetale, les jugulations légères et moyennes de la circulation utérine n'influencent pas la fréquence cardiaque ou provoquent au plus des décélérations mineures et que seules les jugulations trèsfortes causent des décélérations importantes. Par contre, en cas de baisse de la circulation utérine initiale (et de hausse de la fréquence cardiaque foetale), la même jugulation absolue de la circulation produit des décélérations d'amplitude croissante.

Etant admis que les décélérations causées par la jugulation aigue de la circulation sanguine utérine sont provoquées par une chute du $\mathrm{pO}_{2}$ foetal, on a examiné les rapports entre la jugulation de la circulation utérine et la chute du $\mathrm{pO}_{2}$ dans l'artère ombilicale et observé une corrélation linéaire très significative. D'où on conclut qu'il doit exister entre la baisse du $\mathrm{pO}_{2}$ et l'amplitude de décélération les mêmes rapports quantitatifs qu'entre la jugulation de la circulation utérine et l'amplitude de décélération. Si les données présentes parlent en ce sens, les résultats statistiques ne sont pas aussi clairs. Il est possible que la courte constante de temps du $\mathrm{pO}_{2}$ soit à l'origine d'une plus grande fluctuation dans les données du $\mathrm{pO}_{2}$. Par ailleurs, il faut considérer que la baisse progressive du $\mathrm{pH}$ pendant la durée de l'expérience a produit un déplacement de la courbe de dissociation de $\mathrm{O}_{2}$.

Le temps de retard entre le début, d'une part, de la jugulation de la circulation sanguine utérine et, d'autre part, de la décélération de la fréquence cardiaque a été inférieur à $11 \mathrm{sec}$. dans $40 \%$ des cas et inférieur à $21 \mathrm{sec}$ dans $80 \%$ des cas.

Mots-clés: Acidose, cardio-tocographie, circulation sanguine utérine, décélération, expérimentations animales, foetus, fréquence cardiaque foetale, hypoxémie, temps de retard.

\section{Bibliography}

[1] AHLQUIST, R. P., R. A. WOODBURG: Influence of drugs and uterine activity upon uterine blood flow. Fed. Proc. 6 (1947) 305
[2] ASSALI, N. S., K. DA GUPTA, A. KOLIN, L. HOLMS: Measurement of uterine blood flow and uterine metabolism. 
V. Changes during spontaneous and induced labor in unanaesthetized pregnant sheep and dogs. Amer. J. Physiol. 195 (1958) 614

[3] ASSALI, NS, L. W. HOLM, N. SEHGAL: Hemodynamic Changes in Fetal Lamb in Utero in Response to Asphyxia, Hypoxia and Hypercapnia. Circulation Research Vol. 11 (1962) 423

[4] BEHRMANN, R. E., M. A. LEES, E. N. PETERSON, G. W. DELANNOY, A. E. SEEDS: Distribution of the circulation in the normal and asphyxiated fetal primate. Amer. J. Obstet. Gynec. 108 (1970) 956

[5] BERG, D., G. KRONENBERGER, F. KUBLI: Statistische Untersuchungen zur subpartalen Azidose des Feten. Arch. Gynäk. 209 (1970) 34

[6] BORRELL, U., I. FERNSTRÖM, L. OHLSON, $N$. WIQUIST: Influence of uterine contractions on the uteroplacental blood flow at term. Amer. J. Obstet. Gynec. 93 (1965) 44

[7] BRINKMAN, C. R., P. WESTON, T. H. KIRSCHBAUM, N. S. ASSALI: Effects of maternal hypoxia on fetal cardiovascular hemodynamics. Amer. J. Obstet. Gynec. 108 (1970) 288

[8] BROTANEK, V., C. HENDRIKS, T. YOSHIDA: Changes in uterine blood flow during uterine contractions. Amer. J. Obstet. Gynec. 103 (1969) 1108

[9] BROWNE, J. C. M., N. VEAL: The maternal placental flow in normotensive and hypertensive women. J. Obstet. Gynaec. Brit. Emp. 60 (1963) 142

[10] CAMPBELL, A. G. M., G.S. DAWES, A. P. FISHMAN, A. I. HYMAN: Pulmonary vasoconstriction during asphyxia in unmature foetal lambs. J. Physiol. (Lond.) 181 (1965) 47

[11] DAWES, G. S.: The umbilical circulation. Amer. J. Obstet. Gynec. 84 (1962) 1634

[12] DAWES, G. S., S. L. B. DUNCAN, B. V. LEWIS, C. L. MERLET, J. B. OWEN-THOMAS, J. T. REEVES: Hypoxemia and aortic chemoreceptor function in the foetal lamb. J. Physiol. (Lond.). 201 (1969) 105

[13] FISCHER, W. M.: Untersuchungen zum Säure-BasenGleichgewicht im fetalen Blut vor der Geburt. Arch. Gynäk. 200 (1965) 534

[14] FRANKE, R., H. BELLEE, V. SCHÖNJAHN: Sauerstoffpartialdruckmessungen am Foeten unter der Geburt. Gesundheitswesen (1971) 1693

[15] GREISS, F. C.: Effect of labor on uterine blood flow. Observation on gravid ewes. Amer. J. Obstet. Gynec. 93 (1965) 917

[16] HUCH, A., R. HUCH: Einsatz der transkutanen $\mathbf{P O}_{2}-$ Methodik zur fortlaufenden quantitativen $\mathbf{P O}_{2}$ Messung beim Kind sub partu. In: Perinatale Medizin, Band V, S. 180, Thieme, Stuttgart, 1974

[17] KÜNZEL, W., W. MOLL: Uterine $\mathrm{O}_{2}$ consumption and blood flow of the pregnant uterus. Z. Geburtsh. Perinat. 176 (1972) 108

[18] KÜNZEL, W.,F.K. KLÖCK, H. D. JUNGE, W. MOLL: Uterine blood flow, oxygen uptake, and vascular resistance of pregnant sheep near term. J. Perinat. Med. 2 (1974) 101

[19] LIPTON, E. L., A. STEINSCHNEIDER, J. B. RICHMOND: Autonomic function of the neonate: III. Methodological Considerations. Psychosom. Med. 23 (1961) 461
[20] MANN, L. I.: Effects of hypoxia on umbilical circulation and fetal metabolism. Amer. J. Physiol. 218 (1970) 1453

[21] MYERS, R. E., E. MUELLER-HEUBACH, K. ADAMSON: Predictability of the state of fetal oxygenation from a quantitative analysis of the components of late deceleration. Amer. J. Obstet. Gynec. 115 (1973) 1083

[22] PARER, J. T., C. W. DE LANNOY, A. S. HOVERSLAND, J. METCALFE: Effect of decreased uterine blood flow on uterine oxygen consumption in pregnant macaques. Amer. J. Obstet. Gynec. 100 (1968) 813

[23] RAMSEY, E. M., G. W. CORNER, M. W. DONNER: Serial and cineradiographic visualisation of the maternal circulation in the primate (hemochorial) placenta. Amer. J. Obstet. Gynec. 86 (1963) 213

[24] RENOU, P., W. NEWMAN, J, LUMLEY, C. WOOD: Fetal scalp blood changes in relation to uterine contractions. J. Obstet. Gynaec. Brit. Cwlth 75 (1968) 629

[25] RUDOLPH, A. M.: The course and distribution of the foetal circulation. In: WOLSTENHOLME, G. E. W., Ed. Foetal autonomy. A Ciba Foundation Symposion, Churchill, London 1969

[26] SAliNG, E.: Das Kind im Bereich der Geburtshilfe. Thieme, Stuttgart 1966

[27] SCHULZ, J., K. WERNICKE, D. BERG: Neue Erkenntnisse über den Zusammenhang bestimmter Herzfrequenzalterationen von der fetalen Ausgangslage. In: Perinatale Medizin, Band IV, S. 233. Thieme Verlag Stuttgart 1973

[28] VAllbonA, C., M. M. DESMOND, A. J. RUDOLPH, L. FISHER, R. M. HILL, R. R. FRANKLIN, J. B. RUSH: Cardiodynamic studies in the newborn. II. Regulation of the heart rate. Biol. Neonat. 5 (1963) 159

[29] WALKER, A., L. PHILliPS, L. POWE, C. WOOD: A new instrument for the measurement of tissue $\mathrm{pO}_{2}$ of human fetal scalp. Amer. J. Obstet. Gynec. 100 (1968) 63

[30] WERNICKE, K., J. SCHULZ, D. BERG: Kontinuierlich registrierter fetaler Sauerstoffdruck und seine Beeinflussung durch mütterliche Faktoren. In: Perinatale Medizin, Band IV, S. 236 Thieme Verlag, Stuttgart 1973

[31] WILDER, J.: Modern psychophysiology and the law of initial value. Am. J. Psychotherapy 12 (1958) 199

[32] WILDER, J.: Basimetric approach (Law of initial value, liv) to biologic rythms. Ann. N.Y. Acad. Sci. 98 (1962) 1211

[33] WRIght, H., G. PAYLING, N. MORRIS, S. B. OSBORN, A. HART: Effective uterine blood flow during labor. Amer. J. Obstet. Gynec. 75 (1958) 3

[34] WULF, H., W. KÜNZEL, V. LEHMANN: Vergleichende Untersuchungen der aktuellen Blutgase und des Säure-Basen-Status im fetalen und maternellen Z. Geburtsh. Gynäk. 167 (1967) 113

Priv. Doz. Dr. Heinz-Dieter Junge Department of Obstetrics and Gynecology University of Wïrzburg Josef-Schneider-Str. 4 D-8700 Würzburg 